\title{
Accounting
}

\section{The effect of political factors on FDI attraction in Vietnam}

\author{
Trung Kien $V u^{a^{*}}$
}

\begin{tabular}{l}
${ }^{a}$ Academy of Politics Region II, Vietn \\
\hline C H R O N I C L E \\
\hline Article history: \\
Received May 152020 \\
Received in revised format May \\
162020 \\
Accepted July 62020 \\
Available online \\
July 122020 \\
\hline Keywords: \\
Political factors \\
FDI \\
Transparency \\
Business Policies \\
Political characteristics
\end{tabular}

\section{A B S T R A C T}

\begin{abstract}
Attracting foreign direct investment (FDI) to contribute to Vietnam's limited development resources is an objective and indispensable activity. In fact, the investment attraction activities have gained many important achievements in stimulating economic development, curbing inflation and creating jobs. Nevertheless, in many prior studies, there were less discussion on the important role of political factors in the relationship with FDI attraction in Vietnam. Therefore, this study aims to explore that relationship through three variables such as the transparency, the similarity in political characters, and business policies. The findings show the significant effects of those studied factors on the FDI attraction within Vietnam context.
\end{abstract}

\section{Introduction}

The COVID-19 pandemic has affected comprehensively and extensively to all countries in the world, and it is now continuing to develop in a very complicated manner. The global economy is in a serious recession. Vietnam's economy has great openness, extensive international integration has been affected by many impacts, seriously affecting all socio-economic fields, disrupting the supply chain and trading flows. Nevertheless, by well-managed of the pandemic, Vietnam has currently risen as potential emerging market in Asian market context (Kumar and Gray, 2013; Shim, 2006; Nguyen et al., 2020), by that fact, it triggered parallelly either desires of growing business of Vietnamese entrepreneurs individually or the need of expanding international market of multi-national corporations (MNCs). Although Vietnam's business environment has improved positively, the business community still believes that the enterprise has to bear the burden of formal costs derived from the enforcement of legal regulations, laws and policies of the state. In recent times, Viet Nam has joined international organizations, especially the ASEAN Economic Community (ACE), and most lately, has signed the Trans-Pacific Partnership agreement (TPP), the levels of competition among businesses have been getting tougher (Lewis \& Moise, 2018). Nguyen et al. (2019) investigated the capacity of tax authorities and its impact on transfer pricing activities of FDI enterprises in Vietnam. In the field of market entry, in general, the steps in the market entry process are strictly implemented, in accordance with the regulations. However, the ineffective implementation at some steps of the market entry process has made the ranking of this index still not as expected. In recent years, the legal framework in the field of market entry has been amended, supplemented synchronously, clearly, and simplified administrative procedures have helped the implementation process achieve many effective results. It also helps to reduce the time for implementing the process of market entry in Vietnam in recent years. If these procedures are strictly followed, ensuring that they are implemented in the same time as the current regulations, the market entry index will certainly have significant improvements (Chaisse and Górski, 2018; Usinyn and Gáspár-Szilágyi, 2018; Nguyen \& Do, 2020).

* Corresponding author

E-mail address: kienvt@hcma2.edu.vn (T.K. Vu) 


\section{Literature Review}

Most of the largest FDI-attracting economies in the world, such as the US, EU, Singapore, Hong Kong and Australia, have fairly complete institutional systems following international standards, thus creating a fair business environment, transparency and protection of foreign investors (Jadhav, 2012, Jasmine et al., 2003)). Justice in the American legal system is something that very few countries possessed (Campisi \& Caprioni, 2017). This is considered a strong point of the US compared to many other countries. All companies are treated equally in the United States and must follow the same laws, rules and procedures for conducting business. In addition, with Ongoing reform efforts to create favorable conditions and improve the investment environment, Singapore is recently considered as country with smooth and fast administrative system and effective cooperation between relevant agencies to help businesses operate and grow easily.

The EU's investment policy is also inclined to provide investors with legal stability and certainty, along with a favorable environment for doing business and complying with international rules. The EU has removed all trade barriers that act to hinder free trade. Moreover, the European Union has adopted a popular currency, which acts as a major complement to increased trade in the European Union (Schneider and Frey, 1985).

\subsection{Transparency (abbreviation as TRANS)}

Transparency is always widely mentioned in international practice as a leading criterion for evaluating the discipline and management effectiveness of any organization. Fung (2014) explains that corporate transparency describes the extent to which a company's behaviors can be observed by outsiders. Transparency is one of the basic steps for corporate governance. Schnackenberg and Tomlinson (2016) emphasize transparency as a result of the enforcement of laws, internal regulations, specific regulations and business policies related to corporate decision making. and expand operations for employees, stakeholders, shareholders and the public Thus, from a legal perspective, transparency is understood as the framework of the laws and internal management regulations of the company, which are compulsory to comply with the public disclosure, timely and accurate information. Information related to financial and business activities. Otherwise, A fundamental reason that needs to be mentioned is that the decline in the amount of FDI comes from the internal weaknesses of a country such as unstable macroeconomics, besides issues such as high interest rates and debt. bad, the investment environment loses its appeal (Biglaiser \& Staat, 2010, Schneider \& Frey, 1985)

Vietnam is in the process of strong administrative and institutional reform, hence, foreign investment activities become more active, the demand for Vietnamese enterprises to list or attract capital in foreign markets is increasing day by day. In particular, the financial market in general and the stock market in particular are experiencing strong developments, attracting more and more foreign investors and organizations to seek business opportunities. From international practices to the operational practice of administrative agencies in Vietnam, it can be seen that the strict enforcement of the principle of transparency plays an important role in facilitating foreign investment and the level of transparency depends on the capacity and performance of supervisory agencies. Therefore, the hypothesis is formed up as below:

$\mathrm{H}_{1}$ : Transparency has an impact on attracting FDI.

\section{2. geopolitical, cultural and linguistic (abbreviation as GCL)}

The proximity of geopolitical, cultural and linguistic relations also explains the flow of FDI between countries (Azam, 2009). This can be explained by the special historical, political, cultural and linguistic relationship between these economies. In term of international trade, this is an activity where an enterprise will export goods and services to consumers in another country or import foreign goods and services into its country. A country's goods and services are products of that culture (Büthe and Milner, 2008). Therefore, from a cultural perspective, international trade is the transfer of products and services produced from one culture for use by people from another culture. For any business that introduces a product to a foreign market, the first factor to consider is whether the product fits the needs, tastes, or in other words, is appropriate for culture of indigenous customers or not, rather than trying to change the culture to suit the products they produce. Granted, each company has strong and key products in the business. and have been successful in a certain market, but cultural differences in new markets often require the product to correct a few details (Azam, 2009; Biglaiser and Staat, 2010, Schneider and Frey, 1985; Tran, 2020).

With comparative advantage in culture, politics, geography, FDI enterprises will benefit from minimizing the cost of moving production and still maintain a close relationship with the existing production facility. The similarity in political institutions also contributes to help FDI enterprises possessing a favorable commencing in exploration, development, and strict compliance with laws in the host country. As a result, the hypothesis is proposed as follow

$\mathrm{H}_{2}$ : Geopolitical, cultural, and linguistic factors have impacts on attracting FDI. 


\subsection{Business Policies (abbreviation as BP)}

Business policies have a significant impact on enterprises. These policies can increase the level of supply of entrepreneurs or restrict the development of new ventures. Respectively, the policies may be hard or soft. Hard policies usually provide assistance in the form of finance (loans and grants), otherwise, soft policies include counseling activities to entrepreneurs facilitating financial assistance, enhancing technology and access to technology and improving access to physical infrastructure.

By that fact, many researches point out that many factors influence investment behavior such as investment intent; stability of investment environment; the development of the financial system; interest rate policy; public investment policy; the development of supporting industries or projects in the same industry where there are links; ability to acquire and apply and develop technology; support capacity and investment support policy of the country that attracts investment (Bucci, 2002; Knowles and Owen, 1995; Romer and Lucas, 1988; Shefer and Frenkel, 2005). As a result, the hypothesis is proposed as follow

$\mathrm{H}_{3}$ : Business policy factor has an impact on attracting FDI.

\section{Research Methodology}

The study consists of two main steps: qualitative research and quantitative research.

Qualitative research is conducted by in-depth interview method. With this method, the target is a group of representative firms receiving FDI funding in HCM City. This research aims to explore and adjust the scale of political factors that affect the FDI's attraction. Quantitative research includes Preliminary quantitative study, conducted a survey from 100 to 150 representatives of FDI firms mentioned above to check their trustful, unidirectional and convergent validity. The official quantitative research, intensive survey was carried out by creating a questionnaire. Based on the study of sample size to make the selection of the appropriate number of samples. According to Bollen (1989), sample size was proportional to variables of 5:1; however, Hair et al. (2009) said that the minimum sample size was from 100 to 150. Data collection and analysis: The data collection was officially based on representatives of firms facilitating from the FDI receiving sector as mentioned above. After getting the data, we started the Exploratory Factor Analysis (EFA). Scale of trustful was judged by Cronbach's Alpha, the unsuitable variables would be removed. The next step was to affirm the scale by analyzing confirmatory factor (Confirmatory Factor Analysis CFA), the model trustful was judged by composite reliability, convergent validity and discriminant validity. Finally, analyzed theoretical model by structural equation modeling - SEM.

\section{Findings}

Through Table 1, the load of the observed variables ranged greater than 0.6. Cronbach's alpha ranges from 0.726 to 0.768 . The results below showed that the scales achieved convergence validity and reliability.

Table 1

Reliability and Validity results

\begin{tabular}{lcccccc}
\hline Variables & Items & Mean & SD & \multicolumn{2}{c}{ Loadings } & \multicolumn{2}{c}{ Cronbach's } \\
& & & & EFA & CFA & Alpha \\
\hline TRANS & TRANS2 & 4.11 & 0.683 & 0.650 & 0.72 & 0.759 \\
& TRANS3 & 4.03 & 0.690 & 0.748 & 0.71 & \\
\hline GCL & TRANS4 & 4.01 & 0.682 & 0.620 & 0.72 & \\
& GCL1 & 3.81 & 0.779 & 0.685 & 0.71 & 0.768 \\
& GCL2 & 3.85 & 0.767 & 0.700 & 0.77 & \\
\hline BP & GCL4 & 3.73 & 0.794 & 0.742 & 0.69 & \\
& BP2 & 4.11 & 0.668 & 0.664 & 0.65 & 0.726 \\
& BP2 & 4.13 & 0.660 & 0.752 & 0.76 & \\
\hline FDI & BP5 & 3.99 & 0.635 & 0.611 & 0.65 & \\
& FDI & 3.85 & 0.782 & 0.509 & 0.61 & 0.750 \\
& FDI2 & 4.00 & 0.725 & 0.622 & 0.80 & \\
\hline
\end{tabular}

CFA calculating is partially set the basis for SEM, apparently, it provides the establishment of convergent and discriminant indices in order to serve the evaluation of validity construction as well as reliability of instruments. Referred to the likelihood of two measures, the combination of indices such as composite reliability, average variance extracted (Anderson \& Gerbing, 1988), maximum shared variance, and maximum BP-construct correlation (Hair et al. 2009); are employed to serve the convergent and discriminant validity via factor loadings. Thus, Table 2 indicated the proper reliability and validity of all instruments as well as the CFA model in Fig. 1 by applying the regulation as CR $>0.7$, AVE $>0.5$, MSV $<$ AVE, and $\sqrt{A V E}>$ 
Max correlation.

Table 2

Convergent and Discriminant findings

\begin{tabular}{lllll}
\hline & CR & AVE & MSV & MaxR(H) \\
\hline TRANS & 0.728 & 0.500 & 0.428 & 0.738 \\
SLV & 0.759 & 0.512 & 0.479 & 0.759 \\
AG & 0.761 & 0.518 & 0.479 & 0.780 \\
FDI & 0.768 & 0.525 & 0.434 & 0.773 \\
\hline
\end{tabular}

Table 3

Model fit indices

\begin{tabular}{lll}
\hline Indices & Criteria & Model \\
\hline$\chi^{2} / \mathrm{df}$ & $<3$ & 2.228 \\
GFI & $>0.8$ & 0.976 \\
CFI & $>0.9$ & 0.980 \\
TLI & $>0.9$ & 0.973 \\
RMSEA & $\leq 0.08$ & 0.041 \\
\hline
\end{tabular}

Statistical indicators such as $\mathrm{X}^{2} / \mathrm{df}=2.228<3, \mathrm{GFI}=0.976, \mathrm{TLI}=0.973, \mathrm{CFI}=0.980$ are greater than $0.9, \mathrm{RMSEA}=0.041$ $<0.05$ all proved that the model is considered appropriate.

\section{Table 4}

SEM results

\begin{tabular}{|c|c|c|c|c|}
\hline Relationship & & & Estimates & P-value \\
\hline FDI & $4-$ & TRANS & 0.188 & 0.032 \\
\hline FDI & $4-$ & SLV & 0.579 & 0.000 \\
\hline FDI & $4-$ & $\mathrm{AG}$ & 0.433 & 0.000 \\
\hline
\end{tabular}

Table 4 illustrates the result of the suggested hypotheses for the suggested research model. As can be seen the table, H1, H2, H3 are significantly supported. Respectively, the highest effect is SLV, at 0.579 , and following by AG and TRANS at 0.433 and 0.188 .

\section{Conclusion and Recommendation}

FDI does not only stop at adding development capital and creating jobs for workers but also contributes to bring new technologies and development for human resources. Accordingly, FDI has been recognized as one of the sources of capital contributing positively to the economic growth of Vietnam. All the stated agencies need to consider and continue building and perfecting the legal system, correcting asynchronous content, adding new regulations to create a gradually completed legal system with international practices. The Government needs to monitor and supervise the implementation of laws on investment and regularly monitoring businesses to promptly detect and handle arising problems. In addition, the government should prioritize welfare facilities to serve social needs such as hospitals, schools, houses, especially, in industrial parks and export processing zones for workers and investors' peace of mind to work. Proposing the government to direct the review to create favorable conditions for the licensing of foreign workers who are experts; tax breaks for bus, truck and motorbike manufacturing, with more specific guidance on severance allowances, job losses, unemployment benefits, and central regulatory issues such as taxes, customs, environmental impact assessments.

Regarding policies, mechanisms, it is necessary to have a policy to prioritize FDI projects in key areas of the Southeast region, especially Ho Chi Minh City, to motivate and link provinces located in the southern key economic region, in order to exploit the strengths and inherent potential of these localities 
The authors would like to thank the anonymous referees for constructive comments on earlier version of this paper.

\section{References}

Anderson, J. C., \& Gerbing, D. W. (1988). Structural equation modeling in practice: A review and recommended two-step approach. Psychological Bulletin, 103(3), 411.

Azam, M. (2009). Social and political factors effects on foreign direct investment in Pakistan (1971-2005). Gomal University Journal of Research, 25(1), 46-50.

Biglaiser, G., \& Staats, J. L. (2010). Do political institutions affect foreign direct investment? A survey of US corporations in Latin America. Political Research Quarterly, 63(3), 508-522.

Bollen (1989). Structural equations with latent variables.

Bucci, A. (2002). When Romer Meets Lucas: on Human Capital, Imperfect Competititon and Growth. Università di Milano, Dipartimento di economia politica e aziendale.

Büthe, T., \& Milner, H. V. (2008). The politics of foreign direct investment into developing countries: increasing FDI through international trade agreements?. American Journal of Political Science, 52(4), 741-762.

Campisi, J. M., \& Caprioni, E. (2017). Social and Political Risks: Factors Affecting FDI in China's Mining Sector. Thunderbird International Business Review, 59(6), 709-724.

Chaisse, J., \& Górski, J. (Eds.). (2018). The Belt and Road Initiative: Law, Economics and Politics. Brill.

Fung, B. (2014). The Demand and need for transparency and disclosure in corporate governance. Universal Journal of ManFDIement, 2(2), 73.

Hair, E. C., Anderson Moore, K., Hadley, A. M., Kaye, K., Day, R. D., \& Orthner, D. K. (2009). Parent marital quality and the parent-adolescent relationship: Effects on adolescent and young adult health outcomes. Marriage \& Family Review, 45(23), 218-248.

Jadhav, P. (2012). Determinants of foreign direct investment in BRICS economies: Analysis of economic, institutional and political factor. Procedia-Social and Behavioral Sciences, 37, 5-14.

Knowles, S., \& Owen, P. D. (1995). Health capital and cross-country variation in income per capita in the Mankiw-Romer-Weil model. Economics letters, 48(1), 99-106.

Kumar, V., Mudambi, R., \& Gray, S. (2013). Internationalization, innovation and institutions: The 3 I's underpinning the competitiveness of emerging market firms. Journal of International Management, 19(3), 203-206.

Lewis, D. J., \& Moise, D. (2018). One Belt One Road (“OBOR”) Roadmaps: the Legal and Policy Frameworks. In The Belt and Road Initiative (pp. 17-58). Brill Nijhoff.

Nguyen, H., Tham, J., Khatibi, A., \& Azam, S. (2019). Enhancing the capacity of tax authorities and its impact on transfer pricing activities of FDI enterprises in Ha Noi, Ho Chi Minh, Dong Nai, and Binh Duong province of Vietnam. Management Science Letters, 9(8), 1299-1310.

Nguyen, D., \& Do, D. (2020). The impact of equity in FDI firms on accountants' loyalty: Application of equity theory and creative application in economics sociological knowledge. Accounting, 6(2), 215-220.

Nguyen, H., Tham, J., Khatibi, A., \& Azam, S. (2020). Conceptualizing the effects of transfer pricing law on transfer pricing decision making of FDI enterprises in Vietnam. International Journal of Data and Network Science, 4(2), 187-198.

Nunnally, J. C., \& Bernstein, C. (2007). IH (1994). Psychometric theory. New York.

Romer, P., \& Lucas, R. E. (1988). On the mechanics of economics development. Journal of Monetary Economics, 22(1), 3-42.

Schnackenberg, A., \& Tomlinson, E. (2016). Organizational transparency: A new perspective on ManFDIing trust in organization-stakeholder relationships, Journal of ManFDIement, 42(7), 1786.

Schneider, F., \& Frey, B. S. (1985). Economic and political determinants of foreign direct investment. World Development, 13(2), 161-175.

Shefer, D., \& Frenkel, A. (2005). R\&D, firm size and innovation: an empirical analysis. Technovation, 25(1), 25-32.

Shim, D. (2006). Hybridity and the rise of Korean popular culture in Asia. Media, Culture \& Society, 28(1), 25-44.

Tran, N. (2020). Applying 2-stage DEA model to evaluate the corporate social responsibility implementing efficiency of FDI firms. Management Science Letters, 10(11), 2491-2500.

Usynin, M., \& Gáspár-Szilágyi, S. (2018). The Growing Tendency of Including Investment Chapters in PTAs. In Netherlands Yearbook of International Law 2017 (pp. 267-304). TMC Asser Press, The Hague.

Yasmin, B., Hussain, A., \& Chaudhary, M. A. (2003). Analysis of factors affecting foreign direct investment in developing countries. Pakistan Economic and Social Review, 41(1/2), 59-75. 


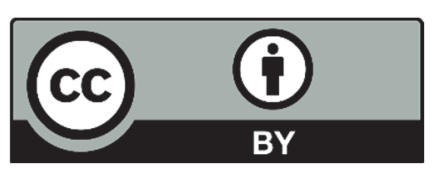

(C) 2020 by the authors; licensee Growing Science, Canada. This is an open access article distributed under the terms and conditions of the Creative Commons Attribution (CC-BY) license (http://creativecommons.org/licenses/by/4.0/). 